\title{
Invasive crayfish impacts on native fish diet and growth vary with fish life stage
}

\author{
Kevin A. Wood ${ }^{1,2} \cdot$ Richard B. Hayes $^{1,3} \cdot$ Judy England $^{3} \cdot$ Jonathan Grey $^{1,4,5}$ (i)
}

Received: 5 August 2015/Accepted: 8 April 2016/Published online: 22 April 2016

(c) The Author(s) 2016. This article is published with open access at Springerlink.com

\begin{abstract}
Assessing the impacts of invasive organisms is a major challenge in ecology. Some widespread invasive species such as crayfish are potential competitors and reciprocal predators of ecologically and recreationally important native fish species. Here, we examine the effects of signal crayfish (Pacifastacus leniusculus) on the growth, diet, and trophic position of the chub (Squalius cephalus) in four rivers in Britain. Growth rates of $0+$ chub were typically lower in sympatric populations with signal crayfish compared with allopatric populations, and this effect could be traced through to $2+$ chub in one river. However, growth rates of older chub (5+ to $6+$ ) were typically higher in the presence of crayfish. Sympatry with crayfish resulted in lower chub length-at-age and mass-at-age in half of the rivers sampled, with no change detected in the other rivers. Stable isotope analyses $\left(\delta^{13} \mathrm{C}\right.$ and $\left.\delta^{15} \mathrm{~N}\right)$ revealed that both chub and crayfish were omnivorous, feeding at multiple trophic levels and occupying similar
\end{abstract}

Electronic supplementary material The online version of this article (doi:10.1007/s00027-016-0483-2) contains supplementary material, which is available to authorized users.

Jonathan Grey

j.grey@lancaster.ac.uk

1 School of Biological and Chemical Sciences, Queen Mary University of London, London E1 4NS, UK

2 Wildfowl and Wetlands Trust, Slimbridge, Slimbridge, Gloucestershire GL2 7BT, UK

3 Environment Agency, Apollo Court, 2 Bishops Square, St Albans Road West, Hatfield AL10 9EX, UK

4 The Wild Trout Trust, PO Box 120, Waterlooville PO8 0WZ, UK

5 Lancaster Environment Centre, Lancaster University, Lancaster LA1 4YQ, UK trophic positions. We found some evidence that chub trophic position was greater at invaded sites on one river, with no difference detected on a second river. Mixing models suggested crayfish were important food items for both small and large chub at invaded sites. This study provides evidence that invasive species can have both positive and negative effects on different life stages of a native species, with the net impact likely to depend on responses at the population level.

Keywords Chub Squalius cephalus · Competition · Diet shift · Invasive species - Scalimetry · Signal crayfish Pacifastacus leniusculus $\cdot$ Stable isotopes

\section{Introduction}

The spread of organisms beyond their natural geographic range is a serious global threat causing both ecological and economic damage (Clavero and Garcia-Berthou 2005; Roy et al. 2012) and rates of invasion show little sign of abating in some systems (e.g. Jackson and Grey 2013). Aquatic ecosystems are particularly vulnerable to the impacts of invasive organisms; the spread of non-native species is often facilitated by human activities and by the rapid dispersal possible in water (Rahel 2007; Strayer and Dudgeon 2010). A number of recent studies have demonstrated that invasive species may increase or decrease the growth rates, and alter the diets of, native organisms through several key mechanisms, including competition, predation, and transmission of pathogens (e.g. Corrreia 2001; King et al. 2006; Maguire and Grey 2006). Where prey availability is affected, a dietary shift to a different or previously under exploited prey resource may occur in order to maintain foraging efficiency (Syväranta and Jones 2008). 
Owing to their omnivory, large body size and potential to dominate benthic biomass, some crayfish have become key invasive species that can affect ecosystem processes, services, and biodiversity, as well as the abundance, distribution, growth, diet and behaviour of native organisms (Lodge et al. 2000). North American signal crayfish (Pacifastacus leniusculus D. 1852) were introduced into Europe in the 1970s for aquaculture and represent one of the most widespread non-indigenous crayfish species (Holdich et al. 2009). Research has tended to focus on the interactions between signal and native crayfish (Holdich et al. 2009; Olsson et al. 2009a; Ercoli et al. 2014) and more recently with other invasive crayfish (Jackson et al. 2014); consequently less is known about interactions with fishes. In rivers, signal crayfish may reduce the growth and abundance of small benthic fishes, through interspecific competition and predation (Guan and Wiles 1997; Light 2005), and out-compete fish for refugia (Griffiths et al. 2004); yet other research has reported no effects of invasive crayfish on juvenile fish survival (Stenroth and Nyström 2003). However, there have been relatively few attempts to assess the specific impacts that signal crayfish may have on larger fish species of ecological and recreational importance (Reynolds 2011; Ruokonen et al. 2012; but see Bašić et al. 2015). Understanding the full-range of crayfish-fish interactions, and both the individual- and population-level consequences are essential if fish populations are to be managed successfully.

Our study compared the growth, diet, and trophic position of a native predatory fish when found in allopatry and sympatry with signal crayfish, and tested three hypotheses. Our first hypothesis was that fish growth rates would be lower at invaded sites because signal crayfish have been shown to reduce the availability of many prey taxa, such as aquatic invertebrates (Stenroth and Nyström 2003; Crawford et al. 2006), benthic fishes (Guan and Wiles 1997), and macrophytes (Nyström et al. 1996). Such changes in prey availability led to our second hypothesis; that fish diet would change after crayfish invasion by shifting to increased use of prey items typically unavailable to crayfish, such as terrestrial invertebrates. Our third hypothesis was that the impacts of crayfish upon fish would be greater for smaller relative to larger individuals via reciprocal predation as well as competition, with each species consuming particular life stages of the other species. Crayfish predominantly feed on fish eggs and larvae, but will also attack small individuals, whereas fish consumption of crayfish typically increases with fork length and hence is greater for adult fish (Hellawell 1971b; Blake and Hart 1995; GarcíaBerthou 2002; Gladman et al. 2012).

We tested our hypotheses using chub (Squalius cephalus L.), native to rivers across Europe, and a potential competitor and reciprocal predator of invasive crayfish. Chub are omnivorous, foraging on aquatic and terrestrial invertebrates, macrophytes, detritus, fishes and other small vertebrates (Hellawell 1971b; Mann 1976) and are popular with anglers. Impacts on chub growth and feeding could alter food web structure, energy flow, community composition and the recreational value of lowland rivers. Thus, juvenile chub would experience reduced prey availability and increased predation pressure, whereas larger chub would experience smaller reductions in prey availability (with larger gape increasing prey range) and this would be partially offset by the greater inclusion of signal crayfish in their diet (Nyström et al. 2006).

\section{Materials and methods}

We used two complementary study approaches to assess the effects of signal crayfish on the growth, condition, and trophic position of chub in four lowland British rivers (Table 1). For two rivers (Evenlode and Cherwell), we used a before-after approach to compare effects on chub before and after signal crayfish invasion. From a further two rivers (Rother and Chad Brook), we used a space-fortime approach in which chub from sites with established signal crayfish populations were compared with chub from uninvaded sites upstream on those rivers; within each river we selected invaded and uninvaded sites with comparable hydrological conditions (i.e. discharge), physical structure (i.e. channel width, depth), land use, and ecological communities, in order to avoid such differences confounding our ability to detect the effects of crayfish on chub. Signal crayfish were first recorded in 2000 and 1995, in the Evenlode and Cherwell, respectively, and thus archived scales provided by the Environment Agency from chub caught before 2000 (Evenlode) and 1995 (Cherwell) were used to obtain pre-invasion growth data, while scales from chub spawned after 2000 and 1995 were used to obtain post-invasion data (Environment Agency data 2008). The Rother was invaded by signal crayfish between 1973 and 1975 (Environment Agency data 2008). Extensive sampling indicated that the invaded stretch extended from a weir $\left(51^{\circ} 00^{\prime} 15.16^{\prime \prime} \mathrm{N}, 00^{\circ} 53^{\prime} 04.96^{\prime \prime} \mathrm{W}\right)$ downstream to $51^{\circ} 00^{\prime} 15.07^{\prime \prime} \mathrm{N}, 00^{\circ} 52^{\prime} 54.70^{\prime \prime} \mathrm{W}$; immediately upstream of the weir, from $51^{\circ} 00^{\prime} 11.93^{\prime \prime} \mathrm{N}, 00^{\circ} 53^{\prime} 05.04^{\prime \prime} \mathrm{W}$ to $51^{\circ} 00^{\prime} 09.03^{\prime \prime} \mathrm{N}, 00^{\circ} 53^{\prime} 41.02^{\prime \prime} \mathrm{W}$ was uninvaded. Signal crayfish invaded Chad Brook from the confluence with the River Stour after 2000 to a weir at $52^{\circ} 04^{\prime} 43.71^{\prime \prime} \mathrm{N}$, $00^{\circ} 42^{\prime} 54.31^{\prime \prime} \mathrm{E}$ (Environment Agency data 2008). Thus, the river above the weir to $52^{\circ} 04^{\prime} 49.33^{\prime \prime} \mathrm{N}, 00^{\circ} 43^{\prime} 31.43^{\prime \prime} \mathrm{E}$ was designated as the uninvaded site, while the river below the weir to $52^{\circ} 26^{\prime} 10.99^{\prime \prime} \mathrm{N}, 00^{\circ} 43^{\prime} 46.80^{\prime \prime} \mathrm{E}$ was classified as the invaded site. 
Table 1 A summary of key characteristics associated with each of our four study rivers (Environment Agency data 2008)

\begin{tabular}{lllll}
\hline Parameter & Evenlode & Cherwell & Chad Brook & Rother \\
\hline Catchment area $\left(\mathrm{km}^{2}\right)$ & 430.0 & 943.0 & 47.4 & 346.0 \\
Length $(\mathrm{km})$ & 39.5 & 64.4 & 14.4 & 52.0 \\
Mean annual discharge $\left(\mathrm{m}^{3} \mathrm{~s}^{-1}\right)$ & 3.8 & 5.5 & 0.3 & 2.3 \\
Dominant land use & Arable and pastoral & Arable and pastoral & Arable & Arable and pastoral \\
& agriculture & agriculture & agriculture & agriculture \\
Year crayfish invasion first detected & 2000 & 1995 & Space-for-time & Space-for-time \\
Study approach used & Before-after & Before-after & Yes & Yes \\
Scalimetry used? & Yes & Yes & Yes & Yes \\
Stable isotope analysis used? & No & No & 21 & 19 \\
No. chub (non-invaded site) & 28 & 24 & 34 & 15 \\
No. chub (invaded site) & 40 & & 18
\end{tabular}

\section{Growth rates}

Age estimation based on annuli counts from calcified tissues such as scales has been routinely used for chub (Hellawell 1971a; Mann 1976). Scale-derived growth data allow long-term assessment of the effects of perturbations (i.e. growth pre- and post-crayfish invasion). Chub were sampled by angling in the Rother $(\mathrm{n}=32)$ and Chad Brook $(\mathrm{n}=36)$ during June-September in 2 years: 2008 and 2011. Mass $( \pm 1 \mathrm{~g})$ and fork length $( \pm 1 \mathrm{~mm})$ were determined in the field and three scales were removed from each chub from the flank between the dorsal fin and lateral line. All individuals were returned alive. For the Rivers Evenlode $(\mathrm{n}=68)$ and Cherwell $(\mathrm{n}=58)$, archived scales provided by the Environment Agency from chub caught before 2000 (Evenlode) and 1995 (Cherwell) were used to obtain pre-invasion growth data, while scales from chub spawned after 2000 and 1995 were used to obtain postinvasion data. Scales were examined using a SMZ1000 dissection microscope (Nikon, Japan) and estimates of length-at-age were back calculated using the Fraser-Lee formula, assuming a length of first scale formation of $15.9 \mathrm{~mm}$ (Economou et al. 1991).

\section{Stable isotope analyses}

Stable isotope ratios of carbon and nitrogen vary in a conservative, predictable manner between trophic levels and thus changes in those ratios can be an effective technique in assessing dietary shifts of consumers in response to the invasion of an ecosystem by an alien species (Jackson et al. 2012). Non-destructive sampling is facilitated where tissue such as scales can be sampled, making stable isotope analysis an ideal investigative tool for aquatic ecosystems with small fish populations of conservational or recreational value (Perga and Gerdeaux 2003; Grey et al. 2009). We used the baseline-corrected estimates of trophic height (sensu Cohen et al. 2003) to compare the trophic position of chub between sites with and without invasive crayfish and mixing models to determine relative contributions from food sources. We combined these complementary methods, assessing growth rates by traditional techniques of scalimetry and then analysing the recent $(<2$ years) material for stable isotopes sequestered in the scales (Grey et al. 2009). Scale isotope ratios were converted to muscle ratios to facilitate the comparison with crayfish and prey species.

We analysed $\delta^{13} \mathrm{C}$ and $\delta^{15} \mathrm{~N}$ of chub scales, crayfish, and putative prey to assess the trophic position of chub and crayfish, their diets, and potential dietary overlap. Qualitative sampling was carried out in May 2008 and June 2011 at invaded and uninvaded sites on the Rother and Chad Brook to collect potential dietary resources. Aquatic invertebrates (min. $n=5$ individuals pooled per taxa), macrophytes ( $n=5$ leaves pooled from different individual plants of the dominant species present), and small fish ( $n \geq 5$ per species) were obtained by kick sampling; terrestrial invertebrates ( $n=5$ individuals pooled per species) were obtained by sweeping riparian vegetation with a butterfly net. Detritus $(\sim 250 \mathrm{~g})$ was taken from the main channel substrate. Signal crayfish were also collected from invaded sites at Chad Brook $(n=18)$ and the Rother $(n=19)$ by kick-sampling. Carapace length was determined for each individual by measuring from the rostrum tip to carapace posterior. All samples except chub scales were frozen at $-20{ }^{\circ} \mathrm{C}$ until preparation for stable isotope analysis. A portion of the outer section of each scale, equivalent to the most recent two annuli, was removed for stable isotope analysis. Each sample was macerated in a glass vial and oven dried at $60{ }^{\circ} \mathrm{C}$ for $48 \mathrm{~h}$, then pulverised using an agate mortar and pestle, and $0.6 \pm 0.05 \mathrm{mg}$ weighed into tin cups. Samples were combusted using an elemental analyser (Flash EA, 1112 series, Thermo-Finnigan) coupled to a continuous flow isotope ratio mass 
spectrometer (Finnigan MAT DeltaPlus, ThermoFinnigan).

Chub and crayfish stable isotope ratios were derived from scale and muscle, respectively. Both $\delta^{13} \mathrm{C}$ and $\delta^{15} \mathrm{~N}$ vary between tissue types, but previous studies have shown that there is a dependable relationship between fish muscle and scale (e.g. Grey et al. 2009). Therefore, to better compare chub to their diet and to the crayfish, a conversion factor was derived from the stable isotope ratios for both scale and muscle tissue. Fifteen chub of three age classes $(0+, 1+$, and $2+; n=5$ for each class) from Calverton Fish Farm (Nottingham, UK), were sacrificed; muscle was excised from the left flank above the lateral line, and both scale and muscle samples prepared as above.

\section{Statistical analyses, isotope-metrics and mixing models}

Statistical analyses were performed using $\mathrm{R}$ version 3.1.2 (R Development Core Team 2015), with significant effects attributed where $p<0.05$. For both our before-after
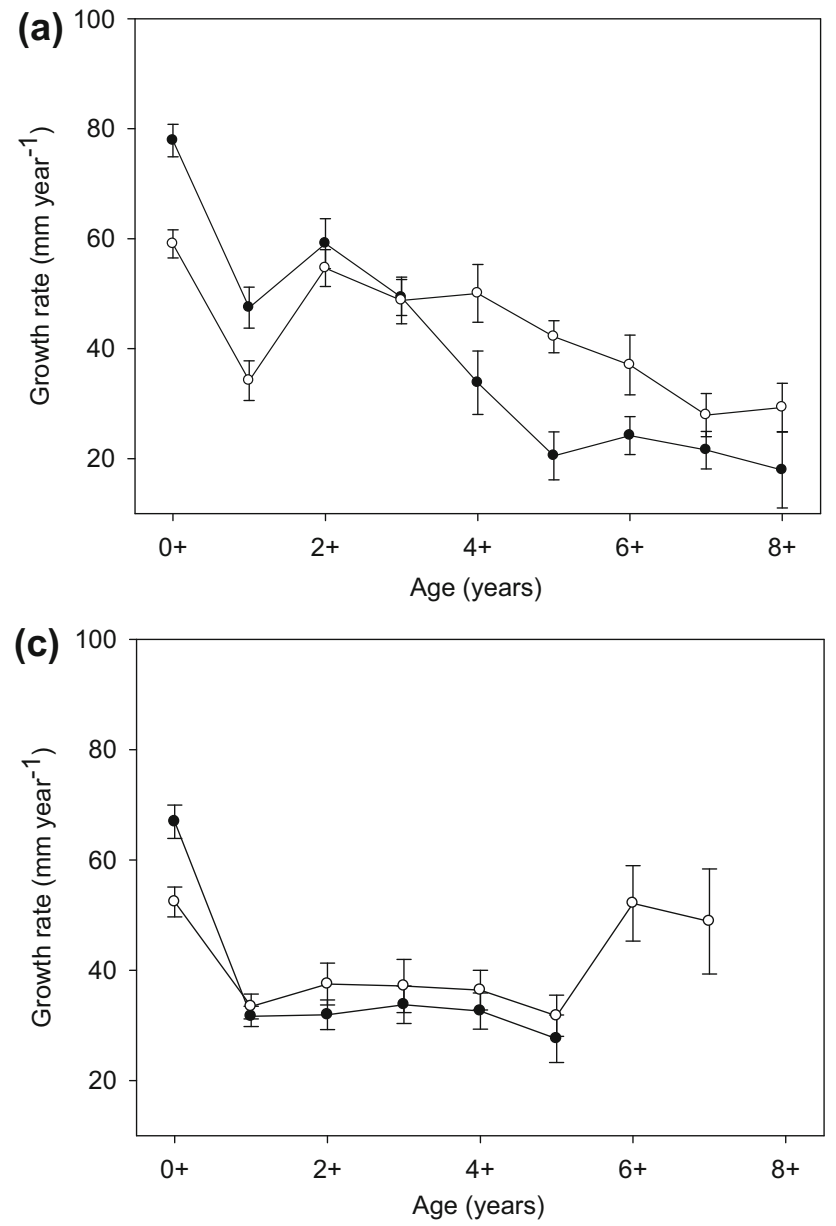

invasion sites (Evenlode and Cherwell) and our space-fortime sites (Rother and Chad Brook) we tested the effects of site (invaded versus uninvaded) and sampling year (2008 vs 2011; Rother and Chad Brook only) on (1) chub growth rates for each age-class, and (2) trophic position (baselinecorrected $\delta^{15} \mathrm{~N}$ ), using linear models with Gaussian error structures. Site and year were treated as fixed factors. Analysis of covariance (ANCOVA) was used to test for differences in the relationships between (1) fork length and age, (2) mass and age, and (3) trophic position and fork length, between invaded and uninvaded sites. Sampling year (2008 or 2011) was also included as a covariate. Normality and equality of variances were ascertained for residuals via Anderson-Darling and Levene's tests, respectively. Linear regressions were plotted through six basal consumers (invertebrates; three terrestrial, three aquatic) for both the Rother (Aquatic: Trichoptera, Amphipoda, Ephemeroptera; Terrestrial: Coleoptera, Hemiptera, Hymenoptera) and Chad Brook (Aquatic: Gastropoda, Amphipoda, Heteroptera; Terrestrial: Coleoptera, Hemiptera, Diptera), and the perpendicular
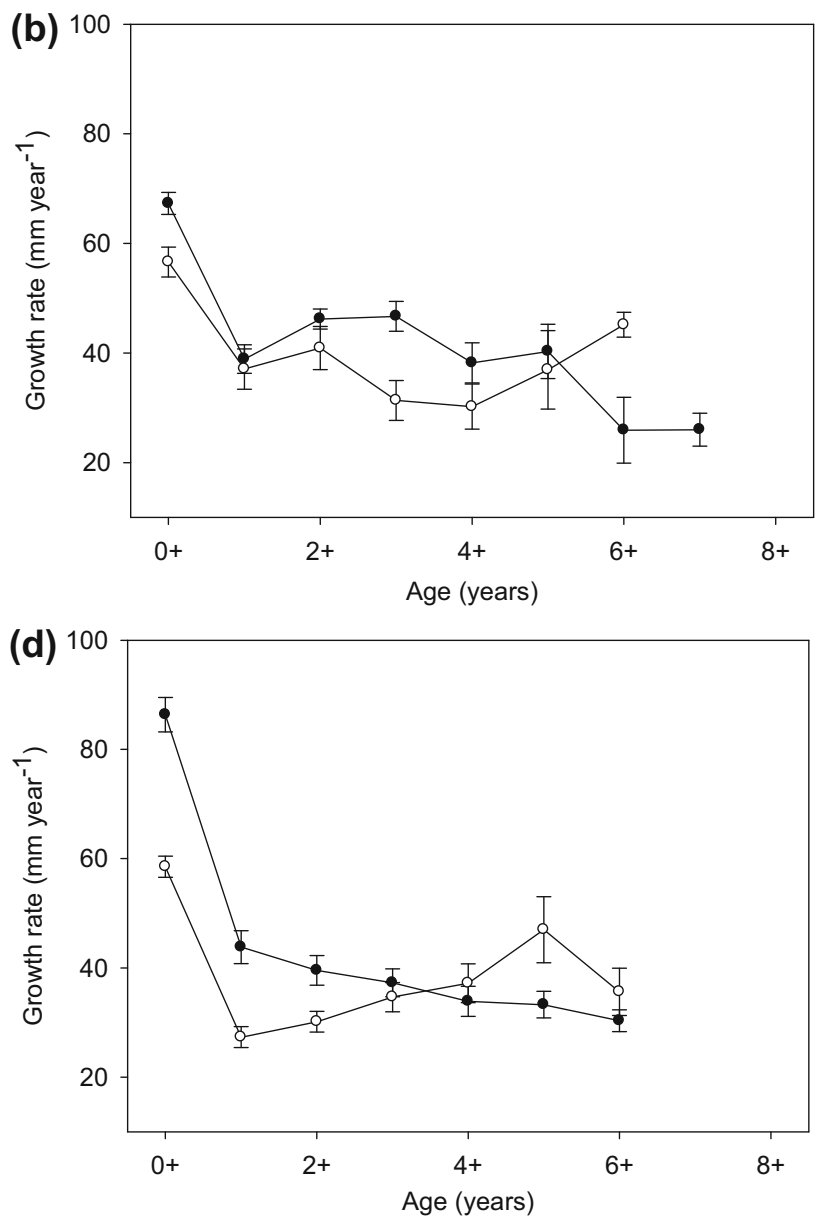

Fig. 1 A comparison of calculated mean $( \pm \mathrm{SE})$ yearly growth rates of chub sampled from uninvaded (closed symbols) and invaded (open symbols) sites on a the Rother, b Chad Brook, $\mathbf{c}$ the Cherwell, and $\mathbf{d}$ the Evenlode 
distance from the generated sloping baseline to the chub or crayfish (measured as change along the $\delta^{15} \mathrm{~N}$ axis) gave the trophic height for each individual.

Chub diet shifts ontogenetically, with Hellawell (1971b) reporting that $\leq 5+$ chub consumed greater proportions of terrestrial and aquatic invertebrates (excluding crayfish), and less plant matter than $\geq 6+$ chub. The mean length of a $5+$ chub, based on data from this study and a meta-analysis of chub length-at-age data (Mann 1976) was $231.7 \mathrm{~mm}$. Thus, to account for potential ontogenetic shifts, chub were classified on fork length as either small $(<232 \mathrm{~mm}$; Rother, uninvaded $n=4$, invaded $n=5$; Chad Brook, uninvaded $n=2$, invaded $n=12)$ or large $(\geq 232 \mathrm{~mm}$; Rother, uninvaded $n=10$, invaded $n=13$; Chad Brook, uninvaded $n=19$, invaded $n=3$ ). The baseline regressions described earlier were used to estimate the mean $( \pm 95 \%$ CI) trophic height of chub and crayfish populations.

SIAR mixing model fractionation values (Parnell et al. 2010) were derived as follows. A mean $\Delta{ }^{13} \mathrm{C}$ value $(2.1 \%)$ was calculated from four controlled feeding studies (Coregonus nasus: $+2.0 \%$, Hesslein et al. 1993; Oncorhynchus mykiss: $+1.3 \%$, Rounick and Hicks 1985; Oncorhynchus mykiss: $+1.9 \%$; Salvelinus fontinalis: +3.3\%o McCutchan Jr et al. 2003). As chub are omnivorous and the fractionation can be dependent on the nitrogen content of food items, a value of $+2.3 \%$ was used for $\Delta{ }^{15} \mathrm{~N}$ following McCutchan Jr et al. (2003). These values were added to all source items under the following categories: crayfish, macrophytes, detritus, terrestrial invertebrates, small fish, and aquatic invertebrates. Cannibalism is not thought to be common among chub (Hellawell 1971b; Mann 1976), and as few individuals were large enough to ingest any other within our samples, cannibalism was excluded from the analysis.

Although crayfish diet has also been reported to vary ontogenetically (Guan and Wiles 1997; Bondar et al. 2005), analysing crayfish in various size classes had negligible effects on SIAR output and therefore crayfish were analysed as a single group. A $\Delta^{13} \mathrm{C}$ value of $+2.0 \%$ was taken from a feeding experiment using Procambarus clarkii (Rudnick and Resh 2005) while $+2.3 \%$ was used once more for nitrogen for the same reasons as for chub. As cannibalism in signal crayfish has been reported, crayfish were included as a potential food source (Guan and Wiles 1997; Stenroth and Nyström 2003).

\section{Results}

Chub from uninvaded sites on all four rivers exhibited decreasing annual growth rate with increasing age (Fig. 1). However, this pattern did not hold for the invaded sections on three of our four rivers, where annual growth rates increased again at ages of $5+$ or above (site dependent). Chub growth rates were significantly lower at invaded relative to uninvaded sites for $0+$ chub in all rivers (Table 2). Whilst there were indications of lower growth rates in $1+$ and $2+$ chub in some invaded river

Table 2 The effects of site (invaded versus uninvaded) and year (2008 vs 2011) on chub growth rates, as indicated by linear models

\begin{tabular}{|c|c|c|c|c|c|}
\hline Age class & Factor & Rother & Chad Brook & Cherwell & Evenlode \\
\hline \multirow[t]{2}{*}{$0+$} & Site & $F_{1,30}=11.44 ; p=0.002$ & $F_{1,34}=13.94 ; p=0.001$ & $F_{1,56}=12.63 ; p=0.001$ & $F_{1,66}=62.95 ; p<0.001$ \\
\hline & Year & $F_{1,30}=2.84 ; p=0.103$ & $F_{1,34}=2.95 ; p=0.095$ & - & - \\
\hline \multirow[t]{2}{*}{$1+$} & Site & $F_{1,30}=1.63 ; p=0.212$ & $F_{1,34}=1.27 ; p=0.268$ & $F_{1,49}=0.36 ; p=0.552$ & $F_{1,64}=23.43 ; p<0.001$ \\
\hline & Year & $F_{1,30}=5.98 ; p=0.021$ & $F_{1,34}=2.14 ; p=0.153$ & - & - \\
\hline \multirow[t]{2}{*}{$2+$} & Site & $F_{1,30}=1.49 ; p=0.232$ & $F_{1,34}=0.68 ; p=0.417$ & $F_{1,35}=1.42 ; p=0.241$ & $F_{1,62}=8.51 ; p=0.005$ \\
\hline & Year & $F_{1,30}=0.79 ; p=0.380$ & $F_{1,34}=0.34 ; p=0.564$ & - & - \\
\hline \multirow[t]{2}{*}{$3+$} & Site & $F_{1,28}=0.06 ; p=0.803$ & $F_{1,32}=3.42 ; p=0.074$ & $F_{1,24}=0.34 ; p=0.565$ & $F_{1,51}=0.50 ; p=0.483$ \\
\hline & Year & $F_{1,28}=0.27 ; p=0.610$ & $F_{1,32}=8.63 ; p=0.006$ & - & - \\
\hline \multirow[t]{2}{*}{$4+$} & Site & $F_{1,18}=3.75 ; p=0.071$ & $F_{1,23}=0.42 ; p=0.524$ & $F_{1,15}=0.55 ; p=0.470$ & $F_{1,41}=0.53 ; p=0.473$ \\
\hline & Year & $F_{1,18}=2.95 ; p=0.582$ & $F_{1,23}=5.05 ; p=0.035$ & - & - \\
\hline \multirow[t]{2}{*}{$5+$} & Site & $F_{1,17}=13.96 ; p=0.002$ & $F_{1,9}=0.13 ; p=0.725$ & $F_{1,13}=0.54 ; p=0.476$ & $F_{1,35}=6.31 ; p=0.017$ \\
\hline & Year & $F_{1,17}=1.32 ; p=0.269$ & - & - & - \\
\hline \multirow[t]{2}{*}{$6+$} & Site & $F_{1,16}=4.76 ; p=0.047$ & $F_{1,6}=18.37 ; p=0.005$ & - & $F_{1,33}=1.49 ; p=0.230$ \\
\hline & Year & $F_{1,16}=1.66 ; p=0.218$ & - & - & - \\
\hline \multirow[t]{2}{*}{$7+$} & Site & $F_{1,16}=0.13 ; p=0.722$ & - & - & - \\
\hline & Year & $F_{1,16}=0.17 ; p=0.691$ & - & - & - \\
\hline \multirow[t]{2}{*}{$8+$} & Site & $F_{1,10}=1.42 ; p=0.264$ & - & - & - \\
\hline & Year & $F_{1,10}=0.11 ; p=0.751$ & - & - & - \\
\hline
\end{tabular}

Significant effects are in bold 
sites, growth rates were only significantly lower in the Evenlode. Older fish from invaded sites exhibited accelerated growth rates compared to uninvaded sites in the Rother at ages 5+ and 6+, at 6+ in Chad Brook, and at $5+$ in the Evenlode (Table 2). Chub growth rates differed significantly between 2008- and 2011-sampled fish in only 3 out of 13 models; $1+$ Rother, $3+$ and $4+$ Chad Brook. Significantly greater fork length-at-age at uninvaded relative to invaded sites was found for Chad Brook and Evenlode (Table 3; Fig. 2). Furthermore, Chad Brook chub achieved greater mass-at-age at uninvaded relative to invaded sites (Table 3; Fig. 2).

There was a linear relationship between chub scale and muscle $\delta^{13} \mathrm{C}\left(F_{1,13}=40.17, p<0.001\right)$, and between scale and muscle $\delta^{15} \mathrm{~N}$ from Calverton fish farm $\left(F_{1,13}=60.51\right.$, $p<0.001$ ). Muscle tissue was ${ }^{13} \mathrm{C}$-depleted (mean $\pm \mathrm{SD}$ : $-2.2 \pm 0.5 \%$ o) and ${ }^{15} \mathrm{~N}$-enriched $(0.8 \pm 0.3 \%)$ relative to scale tissue and the corresponding regression equations shown (Supplementary Information) were used for converting scale isotope ratios for further comparisons.

We found no evidence that chub muscle baseline-corrected $\delta^{15} \mathrm{~N}$ was related to fork length or sampling year at either the Rother or Chad Brook (Fig. 3; Table 3). However, chub baseline-corrected $\delta^{15} \mathrm{~N}$ was higher at the invaded site on Chad Brook, but no differences were detected for the Rother (Fig. 3; Table 3). The relative trophic positions of chub and crayfish, as inferred from isotopic bi-plots (Fig. 4), indicate that both species fed on multiple food sources. Large chub from the invaded Rother site had a mean $( \pm 95 \% \mathrm{CI})$ trophic height (measured as

Table 3 The effects of chub age $(A)$, site ( $S$; invaded versus uninvaded) and year ( $Y$; 2008 vs 2011; Rother and Chad Brook only) on chub fork length $(L)$, and mass $(M)$

\begin{tabular}{|c|c|c|c|c|c|c|c|}
\hline Model & River & Term & $\mathrm{a}( \pm \mathrm{SE})$ & Test statistic & $p$ & d.f. & $R^{2}$ adj \\
\hline \multirow[t]{4}{*}{$L=\mathrm{a} A+\mathrm{a} S+\mathrm{a} Y$} & \multirow[t]{4}{*}{ Rother } & Full model & - & 32.43 & $<0.001$ & 31 & $75.3 \%$ \\
\hline & & $A$ & $31.06( \pm 3.68)$ & 8.44 & $<0.001$ & - & - \\
\hline & & $S$ & $8.67( \pm 20.48)$ & 0.42 & 0.675 & - & - \\
\hline & & $Y$ & $-8.80( \pm 8.40)$ & -1.05 & 0.303 & - & - \\
\hline \multirow[t]{4}{*}{$L=\mathrm{a} A+\mathrm{a} S+\mathrm{a} Y$} & \multirow[t]{4}{*}{ Chad Brook } & Full model & - & 55.80 & $<0.001$ & 35 & $82.5 \%$ \\
\hline & & $A$ & $28.63( \pm 3.16)$ & 9.06 & $<0.001$ & - & - \\
\hline & & $S$ & $-39.60( \pm 10.90)$ & -3.63 & $<0.001$ & - & - \\
\hline & & $Y$ & $6.76( \pm 4.38)$ & 4.38 & 0.133 & - & - \\
\hline \multirow{3}{*}{$L=\mathrm{a} A+\mathrm{a} S$} & \multirow[t]{3}{*}{ Cherwell } & Full model & - & 507.30 & $<0.001$ & 203 & $83.3 \%$ \\
\hline & & $A$ & $32.57( \pm 1.02)$ & 31.83 & $<0.001$ & - & - \\
\hline & & $S$ & $-0.71( \pm 3.19)$ & 0.22 & 0.824 & - & - \\
\hline \multirow[t]{3}{*}{$L=\mathrm{a} A+\mathrm{a} S$} & \multirow[t]{3}{*}{ Evenlode } & Full model & - & 975.90 & $<0.001$ & 299 & $86.7 \%$ \\
\hline & & $A$ & $36.48( \pm 1.01)$ & 36.09 & $<0.001$ & - & - \\
\hline & & $S$ & $-41.16( \pm 3.32)$ & -12.40 & $<0.001$ & - & - \\
\hline \multirow[t]{4}{*}{$M=\mathrm{a} A+\mathrm{a} S+\mathrm{a} Y$} & \multirow[t]{4}{*}{ Rother } & Full model & - & 23.22 & $<0.001$ & 31 & $68.4 \%$ \\
\hline & & $A$ & $135.43( \pm 19.46)$ & 6.96 & $<0.001$ & - & - \\
\hline & & $S$ & $158.98( \pm 108.27)$ & 1.47 & 0.153 & - & - \\
\hline & & $Y$ & $-46.39( \pm 44.39)$ & -1.05 & 0.305 & - & - \\
\hline \multirow[t]{4}{*}{$M=\mathrm{a} A+\mathrm{a} S+\mathrm{a} Y$} & \multirow[t]{4}{*}{ Chad Brook } & Full model & - & 55.60 & $<0.001$ & 35 & $82.4 \%$ \\
\hline & & $A$ & $96.35( \pm 11.49)$ & 8.38 & $<0.001$ & - & - \\
\hline & & $S$ & $-171.11( \pm 39.64)$ & -4.32 & $<0.001$ & - & - \\
\hline & & $Y$ & $-4.08( \pm 15.94)$ & -0.26 & 0.800 & - & - \\
\hline \multirow[t]{4}{*}{$N=\mathrm{a} L+\mathrm{a} S+\mathrm{a} Y$} & \multirow[t]{4}{*}{ Rother } & Full model & - & 3.73 & 0.023 & 31 & $20.9 \%$ \\
\hline & & $L$ & $0.002( \pm 0.002)$ & 0.72 & 0.479 & - & - \\
\hline & & $S$ & $-0.457( \pm 0.354)$ & -1.29 & 0.208 & - & - \\
\hline & & $Y$ & $0.138( \pm 0.188)$ & 0.73 & 0.469 & - & - \\
\hline \multirow[t]{4}{*}{$N=\mathrm{a} L+\mathrm{a} S+\mathrm{a} Y$} & \multirow[t]{4}{*}{ Chad Brook } & Full model & - & 3.60 & 0.024 & 35 & $18.2 \%$ \\
\hline & & $L$ & $0.005( \pm 0.003)$ & 1.60 & 0.119 & - & - \\
\hline & & $S$ & $0.634( \pm 0.298)$ & 2.13 & 0.041 & - & - \\
\hline & & $Y$ & $-0.199( \pm 0.136)$ & -1.47 & 0.151 & - & - \\
\hline
\end{tabular}

We also tested the effects of chub fork length, site, and year on chub baseline corrected $\delta^{15} \mathrm{~N}(N)$ for the Rother and Chad Brook. Test statistics were $F$ and $t$ for full model and individual terms respectively 

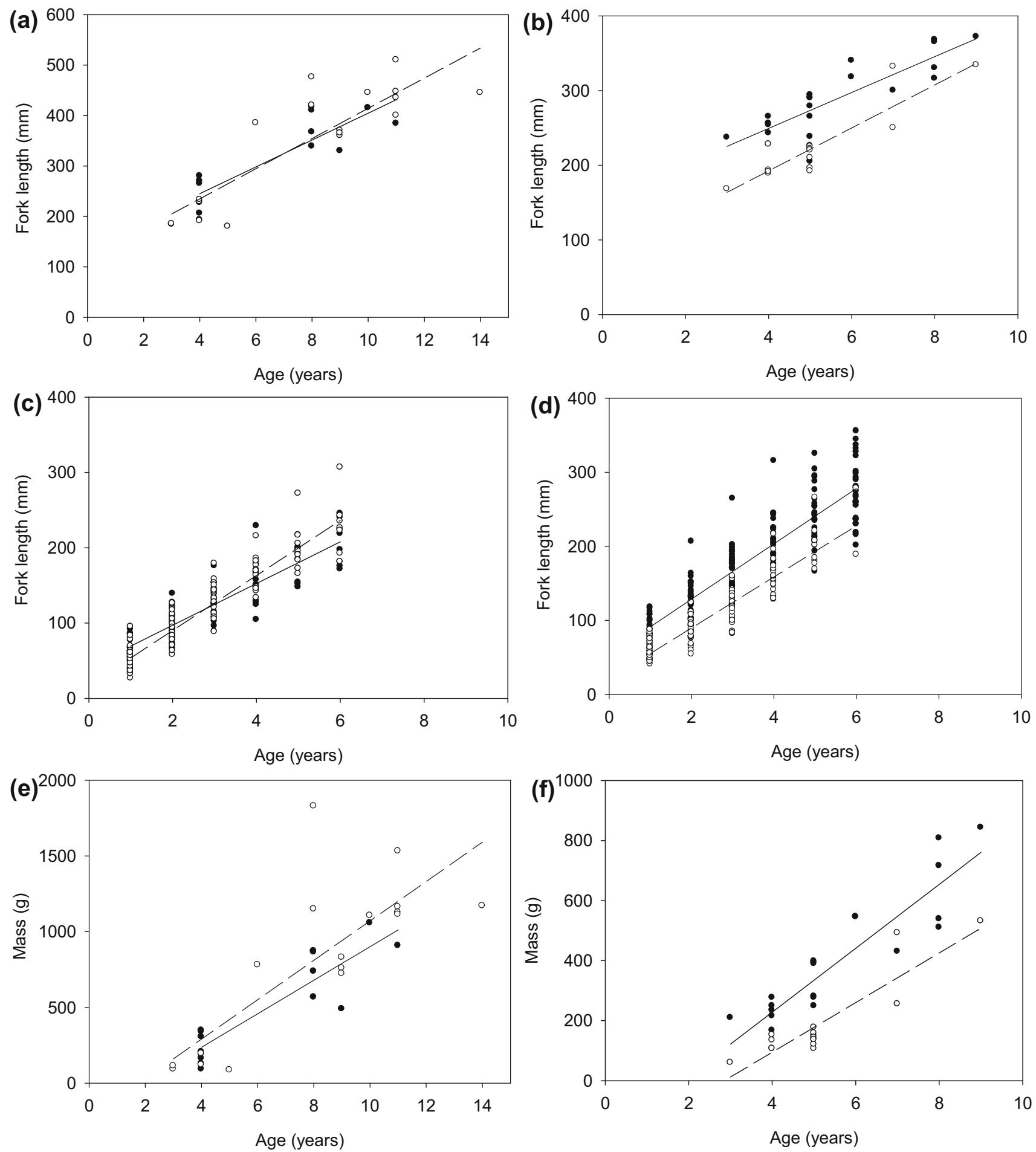

Fig. 2 Chub fork length-at-age at uninvaded (solid circles and line) and invaded (open circles and dashed line) sites on a the Rother, b Chad Brook, $\mathbf{c}$ the Cherwell, and $\mathbf{d}$ the Evenlode. Chub mass-at-age

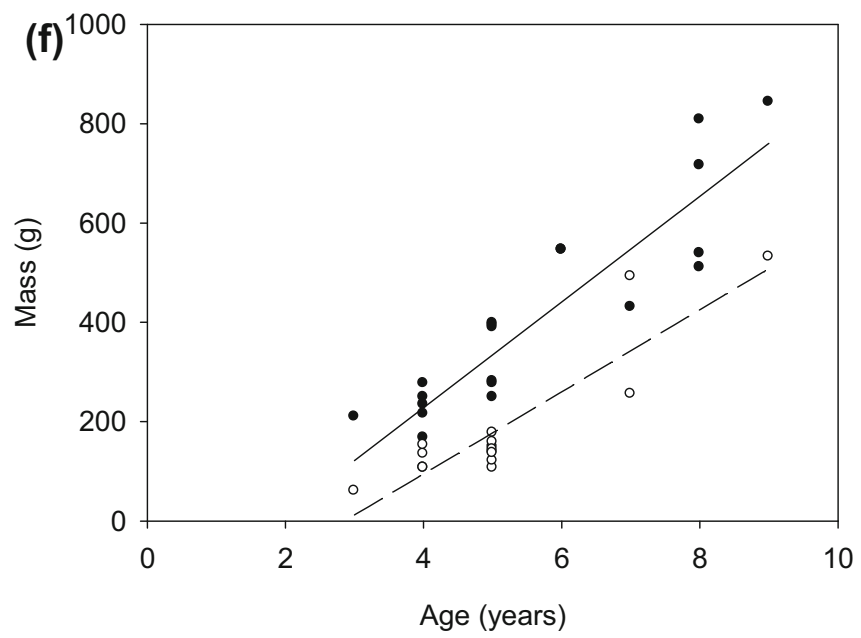

at uninvaded (solid circles and line) and invaded (open circles and dashed line) sites on $\mathbf{e}$ the Rother and $\mathbf{f}$ Chad Brook

heights of large and small chub from the invaded site were 1.1 and $0.8 \%$ higher, respectively, than that of crayfish. However, in Chad Brook both large and small chub were estimated to have similar trophic heights in invaded and 

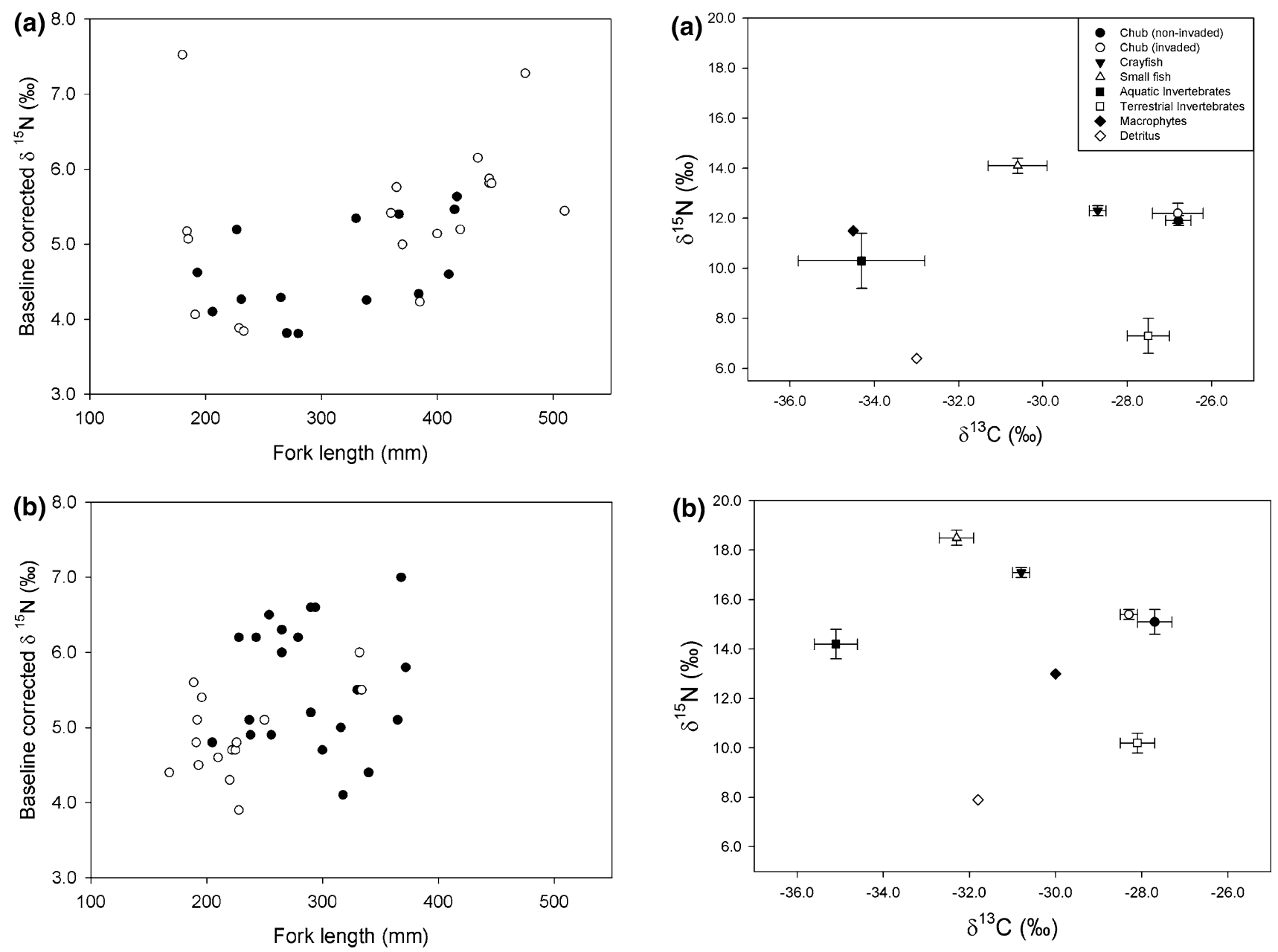

Fig. 3 Baseline corrected chub $\delta^{15} \mathrm{~N}$ as a function of fork length for uninvaded (solid circles) and invaded (open circles) sites on a the Rother and b Chad Brook

uninvaded sites, with crayfish trophic height similar to those of chub (Table 4).

SIAR model ouputs indicated that terrestrial invertebrates were the most important prey resource for chub, comprising up to $50 \%$ of chub diet (Fig. 5; Supplementary Information). In contrast, aquatic invertebrates (other than crayfish) constituted $<20 \%$ of chub diet for all sites on both rivers. Furthermore, small chub relied even less on aquatic invertebrates at invaded sites, declining from 13 to $7 \%$ in the Rother and from 17 to $7 \%$ in Chad Brook. At invaded sites signal crayfish were estimated to make a mean contribution of up to 26 and $19 \%$ of chub diet in the Rother and Chad Brook, respectively. Similar dietary use of crayfish was found for both size classes of chub. For both rivers the contribution of small fish to chub diet was found to be reduced at the invaded sites. Crayfish exhibited a high degree of omnivory in both rivers, with modelled dietary contributions showing wide ranges for all potential food sources (Supplementary Information). Crayfish in

Fig. 4 Isotope bi-plots indicating the mean ( \pm standard error) for chub, crayfish, and the putative prey of both species, for a the Rother and b Chad Brook. For the Rother small fish were 1+ cyprinids, Phoxinus phoxinus, Cottus gobio, and Barbatula barbatula, aquatic invertebrates were Trichoptera, Gammarids, and Ephemeroptera, and terrestrial invertebrates were Formicidae, Arachnidae, Hemiptera, Diptera, and Coleoptera. For Chad Brook small fish were Phoxinus phoxinus, Cottus gobio, Barbatula barbatula, and Gasterosteus aculeatus, aquatic invertebrates were Gammarids, Calopteryx sp., Heteroptera, Limnaea, and Trichoptera, and terrestrial invertebrates Formicidae, Arachnidae, Diptera, Coleoptera, and Gastropoda

Chad Brook showed greater consumption of specific taxa, with aquatic invertebrates and small fish making mean dietary contributions of 42 and $20 \%$, respectively. Cannibalism among signal crayfish was estimated to make a mean contribution of $12 \%$ to crayfish diet in both rivers.

\section{Discussion}

Many studies have reported on the negative impacts of invasive species, but there have been relatively few on how the influence of an invader may be beneficial to a recipient system (Caldow et al. 2007; Letnic et al. 2009; Tablado 
Table 4 The trophic position of chub and crayfish, as measured by the perpendicular distance from a linear regression fitted to six basal resources (sloping isotope baseline) to the consumer $\delta^{15} \mathrm{~N}$ value

\begin{tabular}{llll}
\hline River & Group & \multicolumn{2}{l}{ Baseline corrected $\delta^{15} \mathrm{~N}(\%)$} \\
\cline { 3 - 4 } & & Mean & $\pm 95 \% \mathrm{CI}$ \\
\hline Rother & & & 0.48 \\
Uninvaded & Small chub & 4.54 & 0.44 \\
& Large chub & 4.69 & 1.27 \\
Invaded & Small chub & 5.14 & 0.47 \\
& Large chub & 5.46 & 0.30 \\
Chad Brook & Crayfish & 4.35 & \\
Uninvaded & Small chub & 5.53 & 1.36 \\
& Large chub & 5.58 & 0.38 \\
Invaded & Small chub & 4.74 & 0.26 \\
& Large chub & 5.52 & 0.48 \\
& Crayfish & 5.48 & 0.30 \\
\hline
\end{tabular}

et al. 2010). Our study illustrates that there can be both beneficial and detrimental consequences of invaders on a native species, with the life stage of the native species influencing whether the impact was positive or negative. The growth rates of young individuals of a native fish were reduced when in sympatry with a non-native crustacean, yet some older fish exhibited increased growth rates in the presence of the invader. Our isotope mixing models suggests that crayfish were incorporated as an additional dietary component at invaded sites. Therefore, the influence of the invasive crayfish may be perceived as both negative and positive to chub.

At all sites where chub existed in sympatry with signal crayfish, the $0+$ fish exhibited lower growth rates, and this was maintained in the Evenlode until fish were aged $2+$. Signal crayfish can prey directly upon small fish (Guan and Wiles 1997) and consequently small fish may spend more time engaged in predator-avoidance, limiting foraging opportunities (Light 2005) and reducing growth rates in chub (Allouche and Gaudin 2001). Whilst our results were correlative, a consistent pattern of reduced juvenile chub growth was detected in our four datasets: a space-for-time approach in Evenlode and Cherwell, and a before-after invasion approach in Rother and Chad Brook. Chub growth rates will likely have been further influenced by additional, unmeasured variables, as evidenced by the observed interannual differences in chub growth rates in 3 of 13 comparisons. Such inter-annual differences may reflect betweenyear variation in environmental conditions such as water temperature and flow speed, which are known to influence the growth rates of cyprinid fishes (Cragg-Hine and Jones 1969). Such variables could have interacted with crayfish presence to modulate the effects of crayfish on chub, for example by increasing crayfish numbers or activity (Olsson et al. 2009b). Furthermore, changes in crayfish densities could have affected chub growth rates, as crayfish impacts on native species are typically density-dependent (e.g. Flint and Goldman 1975). Whilst our study did not account for these additional factors, we were still able to detect effects of crayfish invasion on chub growth rates.

Older chub were generally found to exhibit higher growth rates at invaded sites in three of the four rivers studied. The age at which chub from the invaded sites achieved greater growth rates than those of chub from uninvaded sites varied from $5+$ to $6+$. Increased chub growth rates associated with the presence of signal crayfish may indicate greater predation on crayfish by larger chub, a plausible inference considering the ${ }^{15} \mathrm{~N}$ - and ${ }^{13} \mathrm{C}$-enrichment of larger chub. Thus the outputs from the mixing models were consistent with the pattern expected of a gapelimited predator of crayfish. Although Evenlode chub aged $6+$ exhibited slightly higher growth rates in the post-invasion period, the difference was not significant. Overall, the data upheld our first hypothesis, that juvenile chub growth rates would be lower when sympatric with signal crayfish, and older, larger chub would show the opposite trend.

This study provides evidence that signal crayfish may alter the size structure of chub populations. Chub length-atage was reduced at two of the four invaded sites tested; methodology did not appear to influence our results, as reduced length-at-age was detected for sites at which before-after invasion site (Evenlode) and space-for-time (Chad Brook) approaches were used. Furthermore, massat-age was reduced at one of the two invaded sites tested, whereas no increases either length-at-age or mass-at-age in response to invasion were detected, probably due to decreased growth rates of young chub in the presence of signal crayfish. Lower $0+$ growth has been reported to result in smaller annual growth increments across the lifetime of individual chub (Bolland et al. 2007). In the Rother and Cherwell, older $(\geq 5+)$ chub from the invaded sites were found to attain greater length-at-age than conspecifics at uninvaded sites, despite younger $(\leq 3+)$ chub from the same invaded sites exhibiting lower length-at-age values. Based on our complementary stable isotope data, we propose that greater length-at-age in some older chub was the result of consuming invasive crayfish. Our results concur with previous findings that predators can achieve higher post-invasion growth rates and ultimate body size either by direct predation of the invasive species or by indirect effects (King et al. 2006). The changes in chub size-at-age have implications for food web structure and the abundances of prey items as energy requirement and prey availability (due to gape-limitation) are related strongly to fish body size (Wieser 1991). 

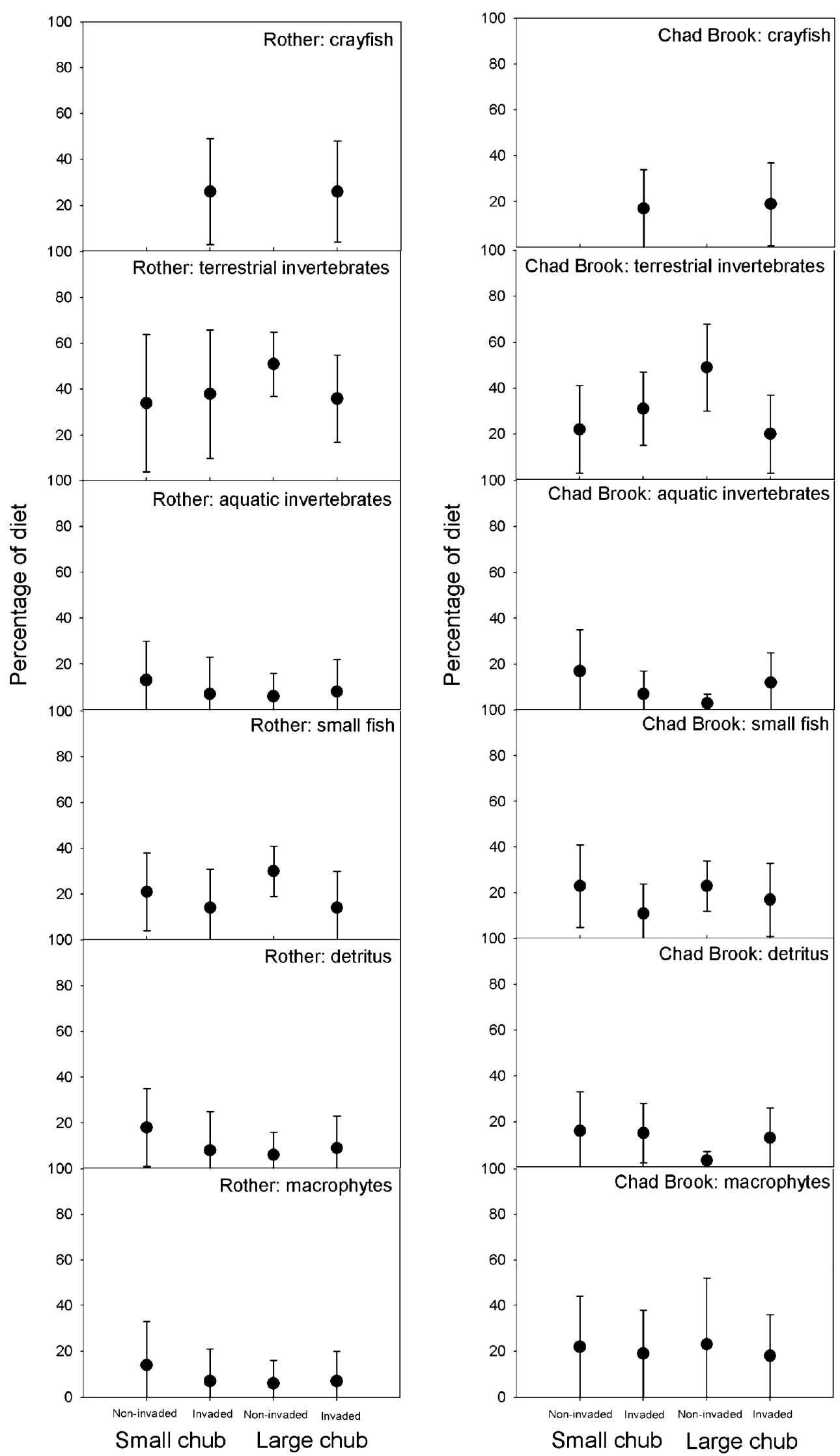
4Fig. 5 The mean $( \pm 95 \% \mathrm{CI})$ percentage of small and large chub diets comprised by each food source at uninvaded and invaded sites, as indicated by the SIAR mixing model. Normal distributions of isotope data were confirmed by visual inspection of the data

Our second hypothesis, that chub diet would be altered in the presence of crayfish, is confirmed not only through the incorporation of the invasive crayfish into the diet of chub, but also by a reduction in reliance upon aquatic invertebrates by small chub, and reduced reliance on small fish by chub of both size classes, at the invaded sites. A reduction in the contribution of one food source must lead to compensation through greater dependence on another. Hellawell (1971b) reported that where larger chub exhibit reduced consumption of terrestrial invertebrates, there was increased consumption of fish, frogs and native crayfish. It is therefore likely that an invasive crayfish would be increasingly exploited in the same manner. Furthermore, considering the documented negative effects of crayfish on aquatic invertebrates and macrophytes, it seems less likely that these groups should be more heavily relied upon by the chub of the invaded sites. Indeed, the reduced contribution of aquatic invertebrates (other than crayfish) to chub diet at invaded sites is consistent with previous research that found invasive signal crayfish reduced the total numbers of aquatic invertebrate by $60 \%$ (Crawford et al. 2006). We found some evidence that the potential incorporation of crayfish into the diets of larger chub resulted in elevated baseline corrected $\delta^{15} \mathrm{~N}$ values at Chad Brook, but not at the Rother. Chub at invaded sites incorporated high $\delta^{15} \mathrm{~N}$ crayfish into their diet, which likely raised large chub $\delta^{15} \mathrm{~N}$ at invaded sites. SIAR output indicated greater consumption of terrestrial invertebrates by chub compared to crayfish. Morphology and behaviour limits crayfish primarily to benthic foraging (Guan and Wiles 1998) and therefore precludes access to surface drifting prey. However, once terrestrial invertebrates sink they become available to crayfish. In contrast, chub utilise the entire water column from benthos to surface when foraging (Hellawell 1971b).

The combined growth data and stable isotope evidence does not support our third hypothesis; that changes in growth rate and dietary shifting would be more pronounced in younger chub. In contrast, the increase in growth rates of older chub at the Rother and Chad Brook were greater in magnitude than those differences between the $0+$ fish. However, as isotope data were only acquired for $\geq 3+$ chub the impact of crayfish invasion on the diet and trophic position of $\leq 2+$ individuals, which exhibited lower growth rates in sympatry with signal crayfish, remain unknown.

We have shown that crayfish invasion can have both positive and negative impacts on the diet and growth of a native fish, using signal crayfish and chub as exemplars. We found some evidence that older chub benefit from the inclusion of crayfish in their diet and can achieve higher growth rates. Younger chub suffer decreased growth rates, probably due to increased predator-avoidance and reduced prey availability. Potentially, an individual chub may experience both negative and positive impacts of invasion as it progresses through different life stages. Whether crayfish invasion can be considered beneficial or detrimental to the native fish population as a whole will depend, at least in part, on whether the lower juvenile growth rates translate into lower recruitment and thus reduced population size. Further longer-term studies of the population level consequences of crayfish invasion are required. Several studies have found lower populations in the presence of signal crayfish (Guan and Wiles 1997; Peay et al. 2009), whereas others have not (Stenroth and Nyström 2003; Degerman et al. 2007); comprehensive studies of fish populations pre- to post-invasion and assessed relative to the 'natural state' (i.e. with the presence of native crayfish) are required to address this question.

Acknowledgments KAW was supported by a NERC Masters Training Grant (NE/E523172/2) awarded to JG. We thank the Environment Agency for part-funding the project, help with site selection and scale provision. Thanks to Michelle Jackson and Nicola Ings for help with isotope analyses, and Rob Britton for help with scalimetry. Tony Wood, Jake Laws, Danny Sheath, Maaike Milligan and Matteo Dossena provided invaluable fieldwork assistance. Views expressed are those of the authors and not their affiliated institutions.

Open Access This article is distributed under the terms of the Creative Commons Attribution 4.0 International License (http://crea tivecommons.org/licenses/by/4.0/), which permits unrestricted use, distribution, and reproduction in any medium, provided you give appropriate credit to the original author(s) and the source, provide a link to the Creative Commons license, and indicate if changes were made.

\section{References}

Allouche S, Gaudin P (2001) Effects of avian predation threat, water flow and cover on growth and habitat use by chub, Leuciscus cephalus, in an experimental stream. Oikos 94:481-492

Bašić T, Britton JR, Jackson MC, Reading P, Grey J (2015) Angling baits and invasive crayfish as important trophic subsidies for a large cyprinid fish. Aquat Sci 77:153-160

Blake MA, Hart PJB (1995) The vulnerability of juvenile signal crayfish to perch and eel predation. Freshw Biol 33:233-244

Bolland J, Britton JR, Cowx IG (2007) Lifetime consequences of variable 0 year group length in riverine populations of chub Leuciscus cephalus (L.). J Fish Biol 71:1810-1819

Bondar CA, Bottriell K, Zeron K, Richardson JS (2005) Does trophic position of the omnivorous signal crayfish (Pacifastacus leniusculus) in a stream food web vary with life history stage or density? Can J Fish Aquat Sci 62:2632-2639

Caldow RWG, Stillman RA, Durell S, West AD, McGrorty S, GossCustard JD, Wood PJ, Humphreys J (2007) Benefits to shorebirds from invasion of a non-native shellfish. Proc Roy Soc B Biol Sci 274:1449-1455 
Clavero M, Garcia-Berthou E (2005) Invasive species are a leading cause of animal extinctions. Trends Ecol Evol 20:110

Cohen JE, Jonsson T, Carpenter SR (2003) Ecological community description using the food web, species abundance, and body size. Proc Natl Acad Sci USA 100:1781-1786

Corrreia AM (2001) Seasonal and interspecific evaluation of predation by mammals and birds on the introduced red swamp crayfish Procambarus clarkii (Crustacea, Cambaridae) in a freshwater marsh (Portugal). J Zool 255:533-541

Cragg-Hine D, Jones JW (1969) The growth of dace Leuciscus leuciscus (L.), roach Rutilus rutilus (L.) and chub Squalius cephalus (L.) in Willow Brook, Northamptonshire. J Fish Biol 1:59-82

Crawford L, Yeomans W, Adams CE (2006) The impact of introduced signal crayfish Pacifastacus leniusculus on stream invertebrate communities. Aquat Conserv 16:611-621

Degerman E, Nilsson A, Nyström P, Nilsson E, Olsson K (2007) Are fish populations in temperate streams affected by crayfish?-a field survey and prospects. Environ Biol Fish 78:231-239

Economou AN, Daoulas CH, Psarras T (1991) Growth and morphological development of chub, Leuciscus cephalus (L.), during the first year of life. J Fish Biol 39:393-408

Ercoli F, Ruokonen TJ, Hämäläinen H, Jones RI (2014) Does the introduced signal crayfish occupy an equivalent trophic niche to the lost native noble crayfish in boreal lakes? Biol Invasions 16:2025-2036

Flint RW, Goldman CR (1975) The effects of a benthic grazer on the primary productivity of the littoral zone of Lake Tahoe. Limnol Oceanogr 20:935-944

García-Berthou E (2002) Ontogenetic diet shifts and interrupted piscivory in introduced largemouth bass (Micropterus salmoides). Internat Rev Hydrobiol 87:353-363

Gladman ZF, Adams CE, Bean CW, Long J, Yeomans WE (2012) Investigating the threat of non-native North American signal crayfish (Pacifastacus leniusculus) to salmon redds. Aquat Conserv 22:134-137

Grey J, Britton JR, Graham CT, Harrod C (2009) Stable isotope analysis of archived roach scales for retrospective study of shallow lake responses to nutrient reduction. Freshw Biol 54:1663-1670

Griffiths SW, Collen P, Armstrong JD (2004) Competition for shelter among over-wintering signal crayfish and juvenile Atlantic salmon. J Fish Biol 65:436-447

Guan R, Wiles P (1997) Ecological impact of introduced crayfish on benthic fishes in a British lowland river. Conserv Biol 11:265-272

Guan R, Wiles P (1998) Feeding ecology of the signal crayfish Pacifastacus leniusculus in a British lowland river. Aquaculture 169:177-193

Hellawell J (1971a) The autecology of the chub, Squalius cephalus (L.), of the River Lugg and the Afon Llynfi. I. Age determination, population structure and growth. Freshw Biol 1:29-60

Hellawell J (1971b) The autecology of the chub, Squalius cephalus (L.), of the River Lugg and the Afon Llynfi. III. Diet and feeding habits. Freshw Biol 1:369-387

Hesslein RH, Hallard KA, Ramlal P (1993) Replacement of sulfur, carbon, and nitrogen in tissue of growing broad whitefish (Coregonus nasus) in response to a change in diet traced by Delta-S-34, Delta-C-13 and Delta-N-15. Can J Fish Aquat Sci 50:2071-2076

Holdich DM, Reynolds JD, Souty-Grosset C, Sibley PJ (2009) A review of the ever increasing threat to European crayfish from non-indigenous crayfish species. Knowl Manag Aquat Ecosyst 394(395): 11
Jackson MC, Grey J (2013) Accelerating rates of freshwater invasions in the catchment of the River Thames. Biol Invasions 15:945-951

Jackson MC, Jackson AL, Britton JR, Donohue I, Harper DM, Grey J (2012) Population-level metrics of trophic structure based on stable isotopes and their application to invasion ecology. PLoS One 7:e31757

Jackson MC, Jones T, Milligan M, Sheath D, Taylor J, Ellis A, England J, Grey J (2014) Niche differentiation among invasive crayfish and their impacts on ecosystem structure and functioning. Freshw Biol 59:1123-1135

King RB, Ray JM, Stanford KM (2006) Gorging on gobies: beneficial effects of alien prey on a threatened vertebrate. Can J Zool 84:108-115

Letnic M, Koch F, Gordon C, Crowther MS, Dickman CR (2009) Keystone effects of an alien top-predator stem extinctions of native mammals. Proc R Soc B Biol Sci 276:3249-3256

Light T (2005) Behavioural effects of invaders: alien crayfish and native sculpin in a Californian stream. Biol Invasions 7:353-367

Lodge DM, Taylor C, Holdich DM, Skurdal J (2000) Nonindigenous crayfishes threaten North American freshwater biodiversity: lessons from Europe. Fisheries 25:7-20

Maguire C, Grey J (2006) Determination of zooplankton dietary shift following a zebra mussel invasion, as indicated by stable isotope analysis. Freshw Biol 51:1310-1319

Mann RHK (1976) Observations on the age, growth, reproduction and food of the chub Squalius cephalus (L.) in the River Stour, Dorset. J Fish Biol 8:265-288

McCutchan JH Jr, Lewis WM, Kendall C, McGrath CC (2003) Variation in trophic shift for stable isotope ratios of carbon, nitrogen, and sulfur. Oikos 102:378-390

Nyström P, Brönmark C, Granéli W (1996) Patterns in benthic food webs: a role for omnivorous crayfish? Freshw Biol 36:631-646

Nyström P, Stenroth P, Holmqvist N, Berglund O, Larsson P, Granéli W (2006) Crayfish in lakes and streams: individual and population responses to predation, productivity and substratum availability. Freshw Biol 51:2096-2113

Olsson K, Stenroth P, Nyström P, Granéli W (2009a) Invasions and niche width: does niche width of introduced crayfish differ from a native crayfish? Freshw Biol 54:1731-1740

Olsson K, Granéli W, Ripa J, Nyström P (2009b) Fluctuations in harvest of native and introduced crayfish are driven by temperature and population density in previous years. Can J Fish Aquat Sci 67:157-164

Parnell AC, Inger R, Bearhop S, Jackson AL (2010) Source partitioning using stable isotopes: coping with too much variation. PLoS One 5:e9672

Peay S, Guthrie N, Spees J, Nilsson E, Bradley P (2009) The impact of signal crayfish (Pacifastacus leniusculus) on the recruitment of salmonid fish in a headwater stream in Yorkshire, England. Knowl Manag Aquat Ecosyst 394(395):12

Perga ME, Gerdeaux D (2003) Using the delta C-13 and delta N-15 of whitefish scales for retrospective ecological studies: changes in isotope signatures during the restoration of Lake Geneva, 1980-2001. J Fish Biol 63:1197-1207

R Development Core Team (2015) R: a language and environment for statistical computing. [3.1.2]. R Foundation for Statistical Computing, Vienna, Austria

Rahel F (2007) Biogeographic barriers, connectivity and homogenisation of freshwater faunas: it's a small world after all. Freshw Biol 52:696-710

Reynolds JD (2011) A review of ecological interactions between crayfish and fish, indigenous and introduced. Knowl Manag Aquat Sci 401:10 
Rounick JS, Hicks BJ (1985) The stable carbon isotope ratios of fish and their invertebrate prey in 4 New-Zealand rivers. Freshw Biol $15: 207-214$

Roy HE et al (2012) Invasive alien predator causes rapid declines of native European ladybirds. Divers Distrib 18:717-725

Rudnick D, Resh V (2005) Stable isotopes, mesocosms and gut content analysis demonstrate trophic differences in two invasive decapod crustacea. Freshw Biol 50:1323-1336

Ruokonen TJ, Karjalainen J, Kiljunen M, Pursianinen M, Hämäläinen H (2012) Do introduced crayfish affect benthic fish in stony littoral habitats of large boreal lakes? Biol Invasions 14:813-825

Stenroth P, Nyström P (2003) Exotic crayfish in a brown water stream: effects on juvenile trout, invertebrates and algae. Freshw Biol 48:466-475
Strayer DL, Dudgeon D (2010) Freshwater biodiversity conservation: recent progress and future challenges. J N Am Benthol Sci 29:344-358

Syväranta J, Jones R (2008) Changes in feeding niche widths of perch and roach following biomanipulation, revealed by stable isotope analysis. Freshw Biol 53:425-434

Tablado Z, Tella JL, Sánchez-Zapata JA, Hiraldo F (2010) The paradox of the long-term positive effects of a North American crayfish on a European community of predators. Conserv Biol 24:1230-1238

Wieser W (1991) Limitations of energy acquisition and energy use in small poikilotherms: evolutionary implications. Funct Ecol 5:234-240 